\title{
Article
}

\section{Development of sustainability indicator scoring (SIS) for the food supply chain}

Manning, Louise and Soon, Jan Mei

Available at http://clok.uclan.ac.uk/17215/

Manning, Louise and Soon, Jan Mei ORCID: 0000-0003-0488-1434 (2016)

Development of sustainability indicator scoring (SIS) for the food supply chain. British Food Journal, 118 (9). pp. 2097-2125. ISSN 0007-070X

It is advisable to refer to the publisher's version if you intend to cite from the work. http://dx.doi.org/10.1108/BFJ-01-2016-0007

For more information about UCLan's research in this area go to

http://www.uclan.ac.uk/researchgroups/ and search for < name of research Group>.

For information about Research generally at UCLan please go to http://www.uclan.ac.uk/research/

All outputs in CLoK are protected by Intellectual Property Rights law, including Copyright law. Copyright, IPR and Moral Rights for the works on this site are retained by the individual authors and/or other copyright owners. Terms and conditions for use of this material are defined in the policies page.

\section{CLoK}

Central Lancashire online Knowledge www.clok.uclan.ac.uk

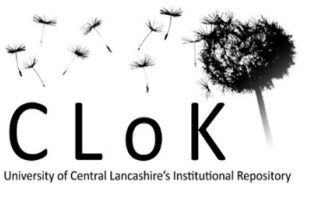




\section{Louise Manningªnd Jan Mei Soon²}

${ }^{1}$ Harper Adams University, Newport, Shropshire, UK TF10 8NB

${ }^{2}$ International Institute of Nutritional Sciences and Applied Food Safety Studies, School of Sport and Wellbeing, University of Central Lancashire, Preston PR1 2HE, UK

\section{Corresponding author ${ }^{1}$ Email lmanning@ harper-adams.ac.uk}

8 Abstract

9 Purpose: The aim of this paper is to identify mechanisms for using a quantitiative benchmarking approach to drive sustainability improvements in the food supply chain.

11 Design/approach/methodology: A literature review was undertaken and then a strategic and 12 operational framework developed for improving food supply chain sustainability in terms of triple 13 bottom line (TBL) criteria.

14 Findings: Using a sustainability indicator scoring (SIS) approach, the paper considers the 15 architecture for analysis so that strategic goals can be clearly formulated and cascade into specific, 16 relevant and timebound strategic and operational measures that underpin brand value and product 17 integrity.

Value: This paper is of value to academics and also practitioners in the food industry.

19 Keywords: food, supply, chain, sustainability, benchmarking, framework 


\section{Introduction}

Sustainability has been defined in many ways, but can be described as offering, the potential for reducing long-term risks associated with resource depletion, fluctuations in energy costs, product liabilities, and pollution and waste management (Shrivastava, 1995). Another widely accepted definition of sustainability is development that meets the needs of the present without compromising the ability of future generations to meet their own needs. This was derived from the Brundtland Commission statement in Our Common Future (World Commission on Environment and Development 1987). Sustainability has also been postulated as the capacity of a system to maintain output at a level approximately equal to or greater than its historical average, with the approximation determined by the historical level of variability (Lynam and Herdt, 1989). Sustainability represents neither a fixed set of practices or technologies, nor a model to describe or impose on the world (Pretty, 1994). Sustainability should therefore first be determined at the highest system level and then proceeds downwards; in the understanding that the sustainability of a system is not necessarily dependent on the sustainability of all its sub-systems (Lynam and Herdt, 1989). Translating this argument to the supply chain level suggests that overall supply chain sustainability is not dependent on every sub-system within that food supply chain being autonomously and individually sustainable. Therefore, supply chain sustainability reflects the sum of the whole i.e. the capacity of the system rather than all activities having mitigated long-term sustainability risk.

Sustainable agriculture should take into account social, environmental and quality of life dimensions (Thompson and Nardone 1999). The "mosaic approach" considers sustainable development as three distinct elements: society (people and welfare conditions), ecology (planet through promoting good environmental practice) and economy (profit through system viability and competitiveness) see the work of Helms (2004). Therefore, the sustainable development of food supply chains means balancing food demand and calorific and nutritional supply whilst efficiently using resources in terms of the 3Ps (planet/environmental, profit/economic and 
people/social) in order to promote human health, product and business longevity otherwise described as the triple bottom line (TBL) by Elkington (1998) and others. Therefore within the current market environment, sustainable products are seen as those products that can accrue value through each stage in the supply chain by product or process differentiation that drives marketing and brand development (Manning, 2015).

\section{Sustainable products}

Sustainable products can be said to generate greater positive or instead lower negative social, environmental and economic impact along the value supply chain than conventional products leading to an active differentiation (Borregaard and Dufey, 2005). This differentiation between commodity and niche products is influenced by the degree of capital investment in developing extrinsic product quality attributes. Product social capital in this case is the trust-based resources associated with a food product that multiply in social networks leading to co-operation among individuals, and collaboration between institutions and community organisations (Muthuri et al. 2006). The challenge for food supply chains and individual businesses within them is to demonstrate quantitatively the value of such social capital for an extended network of stakeholders including governments, non-governmental organisations (NGOs), shareholders and the general public themselves. As a business driver, it could be argued, maintaining shareholder value is as powerful a force as the requirement for organisations to supply food to the ultimate consumer that is safe, affordable and legally compliant (Manning, 2015). Thus some sustainability indicators and frameworks may be developed primarily in order to mitigate shareholder risk.

Along with the notion of sustainability and sustainable products comes the approach of defining individual food product ecological footprints through a benchmarking, often formulaic, approach. Food products have varying ecological footprints depending on the efficiency of the particular path of conversion from the primary to secondary and finally tertiary products. An organisation can seek to minimise the environmental impact of their activities by reducing waste, using 
sequestration. However, many business activities in themselves cannot be defined as sustainable, because they rely upon resources that are both mutually exclusive and finite which creates a hurdle for such resources to be available for future generations. In this context, the aim of this paper is to develop a benchmarking approach that drives sustainability in the food supply chain at a strategic level through the use of a structured sustainability indicator scoring (SIS) framework.

\section{Benchmarking mechanisms for sustainability assessment}

Giving consideration to the primary, or pre-farm gate, stage of production, Halberg et al. (2005) argued for operational benchmarking that focused on identifying best practice, understanding the reasons for differences between farms and then setting goals that improve operational practice. The UK Policy Commission Report on the Future of Farming and Food (Curry, 2002), as did Ronan and Cleary (2000), highlighted benchmarking at an operational level as a mechanism for identifying how a business is operating compared to others in the same sector. Ronan and Cleary (2000) suggested that comparative farm business analysis was based on aggregate measures of whole farm physical and financial performance, such as yield, efficiency, gross margins and farm profit and that this was a different process to activity-based or enterprise benchmarking. They determined that the challenges for implementing benchmarking in the agricultural sector included: professional and industry accreditation of sound benchmarking systems; ensuring appropriate context for farmers' use of benchmarking vis-a-vis complementary to production economic and other financial analyses; achieving greater consistency between different industry systems; lifting participation by farmers in sound industry programs; and evaluating the impact of benchmarking programs on their ability to actually improve farm business performance. These factors also influence how to benchmark effectively at secondary and tertiary supply chain levels too. There are a number of reasons for the lack of mechanisms to measure performance across supply chains (Table 1). These include but are not limited to lack of understanding, geographical and cultural differences, differing organisational goals and objectives and a lack of cohesion between information systems in the supply chain. Andersen and Pettersen (1994) developed three 
categories of benchmarking namely internal, competitive and generic, (the latter two both being external types). Bendell et al. (1993) defined four types, which have been extended using additional literature sources (Table 2).

\section{Take in Tables 1 and 2}

Anderson and McAdam (2004) distinguished between the concepts of "lead" and "lag" benchmarking i.e. "lag" indicators which are based on finance orientated historical measurements and "lead" indicators which instigate the management of real-time change. They further assert that benchmarking has traditionally occurred at the output stage, based on the measurement of lag benchmarks of organisational performance. However, if benchmarking occurs at the input, and/or process stage, these lead benchmarks of performance can be proactive, preventive and drive business strategy within the production cycle. Tangen (2005) differentiated between two types of performance measures, firstly system requirements: criteria which support strategy and the selection of both financial and non-financial performance (i.e. what to do, where the level of compliance can be measured) and secondly measure requirements: criteria which are specific to individual performance measures, (i.e. what is achieved). Therefore the key to effective benchmarking is to determine whether the process will be undertaken at a strategic management level to address an overall supply chain target e.g. reducing waste as a proportion of the product sold at retail level or undertaken at a specific business or at a sub-business activity/enterprise level. A series of operational objectives can therefore be designed to work at single levels in the supply chain that through a mutually concerted process deliver the overarching strategic objective. Metrics that are used to determine sustainability (in its wider sense of people, planet and profit) can only be developed after this strategic: operational interface has been considered and decisions made as to the underpinning objectives of the benchmarking approach. Joung et al. (2013) defined an indicator as a measure or an aggregation of measures from which conclusions on the phenomenon of interest can be inferred. Further, they argued that "standard indicators will 
provide a dependable and repeatable means for manufacturers when they evaluate their level of sustainability and allow comparisons between products, processes, companies, sectors, or countries" (Joung et al. 2013:150). Indicators can be powerful tools for making important dimensions of the environment and society visible and enabling their management (Dahl, 2012). Indicators allow for ranking and in some instances the establishment of competitive league tables and the ability to name, fame or shame and if applied over time can show trends and the direction of travel (Moldan et al. 2012). Metrics or indicators then are one type of sustainability assessment tools and techniques that can track progress over time, identify problems for performance improvement (Tan et al. 2015). Sustainability indicators can be presented in a structured framework that isolates and reports on relevant indicators or alternatively such indicators can be aggregated towards a composite index, score or rating (Dong et al. 2015). Dong et al. (2015) citing Ness et al. (2007) differentiated between three types of sustainability measurement tools:

1) Product-related assessment tools that focus on material and/or energy flow of a product or service with the aim of identifying risks and inefficiencies e.g. the use of life cycle assessment (LCA)

2) Integrated assessment tools with the aim of policy or project implementation through the use of conceptual modelling, multi-criteria analysis, risk and uncertainty analysis, or costbenefit analysis.

3) Indicators and indices - where indicators are used in order to determine the current state of an entity (organisation, country, etc.) with respect to some sustainability category and indices are the result of the standardisation, weighting and/or aggregation of indicators into a single measure or index.

Indicators can be characterised according to their attributes and also by the criteria in which they can be evaluated. Dong et al. (2015) considered how sustainability frameworks can assist in the selection of indicators when constructing an index, and suggested that a dynamic and objective process of indicator selection for both frameworks and composite indices should be developed. 


\section{Development of sustainability indicators}

The purpose of indicators is to simplify real life complex measurements or simulations by models (Girardin et al. 1999). The use of indicators to assess sustainability in primary production has been proposed (Hansen 1996; Bockstaller et al. 1997; Rigby et al. 2001) as well as methods to construct and assess sustainability indicators (Mitchell et al. 1995; Hak et al. 2012). Bell and Morse (2003) stated that sustainability indicators must be: specific (outcome bound); quantitative (measureable): usable (of practical value); available (data easily collated); cost-effective (not expensive to collect); and sensitive (demonstrate changes in circumstances). This does not preclude the use of qualitative indicators, but by their nature qualitative indications do not drive business performance and continuous improvement. Further, Bell and Morse (2003) differentiated between developing an absolute target for compliance and a target that is implemented that defines the direction of travel and thus drives continuous improvement. In the agricultural context, a sustainability target could be an indicator of best practice e.g. an absolute level of pollutant such as nitrate levels per litre of fresh water or a series of "milestones" designating a need for movement as improvements are achieved e.g. climate change levy (CCL) milestones. These criteria may be defined by legislation therefore compliance is mandatory or private market standards whereby compliance affords market entry or maintenance of position within a market or designated supply chain. Therefore, a sustainability target may be developed to deliver a short-term or a long-term goal. This distinction is critical in the understanding of how sustainability indicators are developed and implemented in a food supply chain situation. Bourlakis et al. (2014) differentiate between four supply chain sustainability indicators (efficiency, flexibility, responsiveness and product quality). Measurable indicators such as key performance indicators (KPI) can assist an organisation to demonstrate the implementation of public policy and organisational strategy and identify actual performance against defined sustainable development or corporate social responsibility (CSR) targets. Specific indicators can demonstrate the degree to which the food 
system is resilient, profitable and competitive (Defra, 2010). These are strategic indicators and directed at the supply chain in its entirety rather than just primary production with pre-farm gate sustainability indicators and desired outcomes (Table 3) and post-farm gate and fishing (Table 4). These indicators have been grouped in the synthesis of the literature into four capital groups: financial and physical capital indicators (traditionally reported on the balance sheet), human capital indicators, natural capital indicators and social capital indicators. Although examples for financial and physical indicators are determined in Table 3, in Table 4 these are not identified because they have not been explicitly derived. Indeed the main influence on these factors postfarm gate is market drivers and constraints such as supply and demand and the type of market accessed by the primary producers. The financial sustainability indicators (Table 3) that are suggested in the report include gross value added (GVA) per person, total productivity factor (TPF) and total liabilities as a percentage of total assets. Resource management sustainability indicators suggested by Defra (2010) include water source and irrigation, water usage, diffuse pollution such as leaching of nitrate, phosphorous and crop protection products into water bodies, agriculture's contribution to ammonia emissions and greenhouse gas (GHG) emissions, soil quality, energy use and reducing of waste and GHG emissions, reducing waste. Social sustainability indicators proposed by the report included accessibility and affordability, diet and consumer confidence, traceability of food through the development of assurance systems, management of food borne disease, control of animal disease and promotion of animal welfare, support for biodiversity and habitat management, investment in training, knowledge and innovation. These themes in terms of financial, resource and social indicators are mirrored in the design of multinational corporation (MNC) annual reports and CSR strategy documents and are used to address sustainability in its wider sense. Therefore it could be argued that such MNCs are often acting in a quasi-governmental role, through setting supply chain standards over and above minimum legislation, in their custodianship of many of the factors that impact on food supply chain sustainability. This could allow a national government to step back in their regulatory role 
and allow the market to influence the drive for sustainability in food production rather than through social responsibility lying with the regulators themselves.

\section{Take in Tables 3 and 4}

Veleva and Ellenbecker (2001) asserted that indicators of sustainable production (ISPs) should have the following main objectives:

- Promoting organisational learning and educating business about the nature of sustainable production;

Taylor (2012) critiqued further literature on the selection of sustainability indicators (Table 5).

\section{Take in Table 5}

These sustainability indicators include both qualitative and quantitative metrics and the source highlights the use of indexes that contain multiple metrics rather than a single value e.g. the Environmental Sustainability Index (ESI), and as has been described ecological footprinting. Searcy and Elkhawas (2012) suggest that there are many global sustainability indices linked to financial markets, including the Dow Jones Sustainability Index (DJSI), the FTSE4Good Index, and the MSCI ESG (Environmental, Social, and Governance) Index (formerly known as the KLD and Domini 400 Social Index) as these are being increasingly used to demonstrate corporate 
sustainability and corporate compliance risk which is of key interest to shareholders. The term socially responsible investing (SRI) has been coined in this context but it is important to consider the underpinning risk strategy that investors are using when considering the investments they make and the DJSI and others reflect MNC performance as a whole, not individual products or food supply chains. Nearly all Fortune Global 250 companies have established supply chain standards and report on their supply chain relationships often as a means to demonstrate social responsibility and transparency to their stakeholders (Yakoleva et al. (2010). Sustainability frameworks aim to measure sustainability primarily by providing qualitative evaluations of processes or selected composite TBL characteristics i.e. environmental, social and economic indicators (Dong et al. 2015). However the authors argue frameworks can also effectively serve as guidelines for selecting indicators either for disaggregated 'dashboards' or for composite indices. Examples of sustainability frameworks (Table 6) and sustainability indices (Table 7) have been synthesized from the literature.

\section{Take in Tables 6 and 7}

240 Tan et al. (2015:133) argue that whilst many indicator frameworks are available they are "either 241 too complicated to be adopted by smaller companies or too high level for practical usage". Veleva and Ellenbecker (2001:520) argue that: "while some issues are common for all companies, such as energy use, water use, charitable contributions, work-related injuries and illnesses, the differences between production facilities are enormous and a standardised set of sustainability indicators may miss key impacts." Moldan et al. (2012) suggest that determining baseline, 246 reference values, or initial state indicators is important especially where organisations wish to show a direction of travel and also in the setting of specific targets to be achieved. They argue that the "benefit of specific, quantitative, time bound targets is then straightforward ... indicators can be linked to them and interpreted clearly on a distance-to-target basis." (Moldan et al. 
Böhringer and Jochem (2007) reviewed eleven Sustainability Development (SD) indices with regard

252

253

254

255

256

257 to their consistency and meaningfulness: the Living Planet Index (LPI), Ecological Footprint (EF), City Development Index (CDI), Human Development Index (HDI), Environmental Sustainability Index (ESI), Environmental Performance Index (EPI), Environmental Vulnerability Index (EVI), Index of Sustainable Economic Welfare/Genuine Progress Index (ISEW/GPI), Well- Being Index (WI), Genuine Savings Index (GS), and Environ- mental Adjusted Domestic Product (EDP). They conclude that normalisation and weighting of indicators, generally a subjective judgment reveals "a high degree of arbitrariness without mentioning or systematically assessing critical assumptions". Further they suggest that with regard to aggregation, scientific rules guaranteeing consistency and meaningfulness of composite indices are often not taken into account (Böhringer and Jochem, 2007:7). Joung et al. (2013) considered eleven indicator sets that can operate at the company/organisational level, the national/region level or the global level (Table 8).

\section{Take in Table 8}

Turi et al. (2014) suggest 10 TBL indicators of value at company/organisational level where they can operate equally as well at product level. Yakovleva (2007) and Yakoleva et al. (2010) identified 9 TBL indicators for the food supply chain spanning each dimension (economic, social and environmental) of sustainability. This was based on more than 50 initial indicators that were drawn up by Yakovleva and Flynn (2004) and were screened based on research reports, market reports and statistical data (Table 9). Yakoleva et al. (2010) identified three factors: the development objective, the measurement criteria and the sustainability indicator. In essence, when the indicators are chosen, and the outputs that they drive and/or their appropriateness for the operational or strategic goal identified, then policy makers or in this case individual business operators can utilise this approach to drive effective decision making improved business performance.

\section{Take in Table 9}


Performance measures/metrics must be implemented within a framework starting with a policy maker's or organisation's mission statement and associated policies as the start for developing appropriate measures with characteristics of inclusiveness, universality (allowing for comparison), measurability and consistency with organisation goals (Hervani et al. 2005; Acquaye et al. 2014). Environmental performance and economic performance leverage improves operational performance and in turn enhances organisational performance (Green et al. 2012). Therefore effective approaches to drive improved economic, environmental and social performance must not be just formulaic but allow for an iterative approach to enable baseline data to be collected, intervention measures (i.e. system measures as defined by Tangen, 2005) to be determined and implemented and appropriate KPI developed, adopted and assessed to measure performance. Tan et al. (2015) and others have sought to identify criteria for screening sustainability indicators for their value and determined that the indicators must be understandable, applicable and relevant. Veleva and Ellenbecker (2001) outlined that to construct an indicator a unit of measurement, a period of measurement, definition of the type of measurement, (absolute or adjusted in line with increases or decreases in production), and defined boundaries (e.g. it is of value at product level, facility, with suppliers, or the entire LCA of a material or product) are required. Further they argue such indicators must be appropriate, simple and meaningful; easy to apply and evaluate (verify); be of a manageable number, data driven, allow benchmarking processes to occur and form a combined set of both quantitative and qualitative headline category and sub-category measures.

\section{Development of a framework incorporating Sustainable Indicator Scoring (SIS)}

A sustainability indicator framework can be used at both an operational or a strategic level to provide organisational, supply chain and overarching policy measures that define goals and objectives that are measureable i.e. quantitative. Yakovleva et al. (2010) suggested the possibilities of expanding the application of their framework. Consideration of this and other extant literature described in this paper has led to the development of a simplified conceptual 
framework using sustainability indicator scoring (SIS). There are a myriad of SIS systems using mathematical or statistical exercises, or weighting of parameters giving one indicator more significance than another that allow for comparison between entities (organisations, communities) and afford the ability to have comparable information (Taylor, 2012). Differences in weighting complexity include using statistical models, adopting participatory methods and assigning equal weights to the indicators (Kondyli, 2010 cited by Taylor 2012). The definition of sustainability as highlighted by WCED (1987) takes into consideration the needs of future generations. Hence, it is apt that sustainability can be divided into two components: i) meeting current needs (current status); and (ii) ability to meet future needs (future status).

The data used by Yakovleva et al. (2010) and Yakovleva (2007) had been rescaled and normalised to enable analysis and comparison of data between different stages in the food supply chain. As demonstrated in this paper, multiple sustainability indicators exist of varying complexity. The conceptual framework derived in this research further expands on the nine TBL indicators developed by Yakovleva et al. (2010). Table 10 has been modified from the literature synthesized in Table 9 to develop twelve TBL indicators with two scores being determined to reflect the that could be derived if appropriate actions are implemented at a point of time Peano et al. would define as T1. All the indicators are outcome based, measurable, of practical value, and data can be easily collected, cost-effective and sensitive. shows a need for urgent improvements; actions need to be taken and reassessed after improvement measures have been implemented to determine efficacy; '2' = Low sustainability (LS)- the indicator shows a need for evaluation to determine areas for improvements and the prioritisation for action is high priority. Action needs to be taken and then they should be re-assessed after 
indicator shows improvements are required with medium priority. Action needs to be taken and then they should be re-assessed after improvements have been implemented to determine efficacy; '4' = Average sustainability (AS) the indicator shows a need for evaluation to determine areas for improvements but this is of low priority. Action needs to be taken and then they should be reassessed after improvements have been implemented to determine efficacy; ' 5 ' $=$ Good sustainability (GS) - the indicator shows this area is under control but continuous improvement can still be made to achieve excellent status ' 6 ' $=$ Excellent sustainability (ES) where an organisation can demonstrate sustainability goals are being achieved and documented plans and policies and an associated monitoring and verification system ensure there are formal systems in place to underpin maintaining this level of efficiency.

Thus by scoring each of the twelve indicators individually and adding the scores together the overall current baseline status will be a score of between 0 and 72 . The future status where each indicator can be scored will similarly range from 0-6 for each indicator and between 0 and 72 overall depending on the objectives that are set for each indicator by the business. For example if used: a business scores ' 0 ' at $\mathrm{T} 0$ for a given indicator and on the basis of the proposed action they predict they can achieve fair, average or even good sustainability status at $\mathrm{T} 1$ then the direction of travel can be determined. In order to determine a composite SIS score the following formula is benchmarking assessments are completed for all indicators then, a total SIS score is calculated. The weighted format therefore provides an SIS scale that can range between 0 and 462 and the overall status for the organization or product can be characterised as follows: 
1-72 = Very low sustainability (VLS) i.e. the combined score shows a need for urgent improvements; actions need to be taken and reassessed after improvement measures have been implemented to determine efficacy;

73-144 = Low sustainability (LS) - the score shows a need for evaluation to determine areas for improvements and the prioritisation for action is high priority. Action needs to be taken and then they should be re-assessed after improvements have been implemented to determine efficacy; 145-216 = Fair sustainability $($ FS) the score shows improvements are required with medium priority Action needs to be taken and then they should be re-assessed after improvements have been implemented to determine efficacy;

217-288 = Average sustainability (AS) the score shows a need for evaluation to determine areas for improvements but this is of low priority. Action needs to be taken and then they should be reassessed after improvements have been implemented to determine efficacy; 289-360 = Good sustainability (GS) - the score shows this area is under control but continuous improvement can still be made to achieve excellent status 361-432 = Excellent sustainability (ES) where an organisation can demonstrate sustainability goals are being achieved and documented plans and policies and an associated monitoring and verification system ensure there are formal systems in place to underpin maintaining this level of efficiency.

This approach assists organisations to benchmark their own business and the organisations they interact with in the wider supply chains. The indicators derived in this research are understandable, applicable and relevant for both small, medium sized and large organisations and can be utilised by organisations operating in a number of locations to standard policies and protocols. In line with the criteria put forward by Veleva and Ellenbecker (2001) the twelve indicators are quantitative i.e there is a unit of measurement, a period of measurement i.e. measurement can be determined e.g. quarterly, six monthly or annually, there is definition of the 
in line with increases or decreases in production volumes, and assessment boundaries can be defined e.g. the process can be undertaken of SIS scoring by product, by facility,with suppliers, or the entire LCA of a material or product) are required.

The SIS outlined is of value in providing simplified and meaningful metrics of the degree of sustainability of supply systems especially for an organisation that seeks to protect brand value when they operate over multiple countries with a plurality of cultures and expectations. Organisations face multiple challenges to brand value and corporate integrity that sit under the wider umbrella of sustainability as can be seen with examples such as Nestlé in 2015 with the Maggi noodles incident in India (Nestle, 2015a), labor and human rights (Nestle, 2015b), and Chipotle Mexican Grill Inc. with multiple food safety outbreaks in 2015 and a coincident 28\% drop in share price (MarketWatch, 2015). Therefore a tool such as the one described in this paper is of value to organisations as a template to develop and adopt for supply chain risk assessment in order to mitigate brand risk and underpin brand protection.

\section{Conclusion}

Significant focus has been placed at national policy level, supply chain and individual business on developing, implementing and meeting sustainability goals such as improving food safety, people and animal welfare, and reducing environmental impact. Market influences have also embedded social requirements into quality assurance standards. The challenge for developing sustainability metrics is to seek to bolster organisational performance and this paper proposes the use of metrics that assess the levels of financial return, efficiency, flexibility, product safety and environmental impact. The development of metrics is a highly sophisticated approach and needs to be given great consideration in order to ensure that the activity provides information that is of value and can underpin both strategic objectives and operational activity.

Assurance of food security at a global, regional and local level requires the integrated engagement of supply chain actors at all stage of food production, distribution and information exchange. Therefore, a sustainable supply chain is one that has inbuilt longevity and thus action has been 
404 taken to limit vulnerability. In order to drive a quantitative approach to driving improved 405 sustainability performance an assessment of the architecture of performance analysis needs to be 406 developed. Ultimately, strategic TBL sustainability goals need to be clearly formulated and these 407 need to cascade into specific, relevant and timebound strategic and operational measures that 408 underpin brand value and product integrity.

409 


\section{References}

Acquaye. A., Genovese, A., Barrett, J., Koh, S.C.L. (2014), Benchmarking carbon emissions performance in supply chains, Supply Chain Management: An International Journal, Vol. 19, Iss. 3 , pp. $306-321$

Anderson, A., and McAdam, R., (2004), A critique of benchmarking and performance measurement, Benchmarking: An International Journal, Vol.11, Iss. 5, pp. 465-483

Andersen, B. and Pettersen, P.G. (1994), "The basics of benchmarking: what, when, why and how", Proceedings from the 1994 Pacific Conference on Manufacturing, Djakarta, Indonesia.

Atkinson, G.D., Dubourg, R., Hamilton, K., Munasignhe, M., Pearce, D.W., and Young, C., (1997). Measuring Sustainable Development: Macroeconomics and the Environment. Edward Elgar, Cheltenham.

Bell, S., and Morse S. (2003), Measuring sustainability: learning by doing, Earthscan Publications Ltd, London

Bendell T., Boulter L., and Kelly J. (1993), Benchmarking for Competitive Advantage. Pitman Publishing, London.

Bockstaller, C., Cirardin, P. and van der Werf, H.M.G. (1997), Use of agro-ecological indicators for the evaluation of farming systems. European Journal of Agronomy, Vol. 7, Iss. 1-3, pp. 261270.

Böhringer, C., and Jochem, P.E.P. (2007), Measuring the immeasurable - A survey of sustainability indices, Ecological Economics, Vol.63, pp. 1-8

Borregaard, N., and Dufey, A. (2005), Challenging preconceptions about trade in sustainable products. Towards win-win-win for developing countries, International Institute for Environment and Development, London.

Bourlakis, M., Maglaras, G., Gallear, D. and Fotopoulos, C. (2014), Examining sustainability performance in the supply chain: The case of the Greek dairy sector, Industrial Marketing Management, Vol. 43, pp. 56-66.

Brekke, K.A. (1997). Economic Growth and the Environment: On the Measurement of Income and Welfare. Edward Elgar, Cheltenham and Lyme.

Brewer, P.C. and Speh, T.W. (2001), “Adapting the balanced scorecard to supply chain management”, Supply Chain Management Review, Vol. 5 No. 2, pp. 48-56.

Cobb, C., Halstead, T., and Rowe, J. (1995). The Genuine Progress Indicator: Summary of Data and Methodology. Redefining Progress, CA.

Curry, D. (2002), Farming and food: A sustainable future: Report of the policy commission on the future of food and farming. London, Cabinet Office.

Dahl, A.L. (2012), Achievements and gaps in indicators for sustainability, Ecological Indicators, Vol. 17, pp. 14-19 
Daly, H.E., and Cobb, J.B. (1989). For the Common Good: Redirecting the Economy towards the Community. The Environment and a Sustainable Future, Boston.

Das, D., and Das, N. (2014). Sustainability reporting framework: Comparative analysis of global reporting initiatives and Dow Jones sustainability index. International Journal of Science, Environment and Technology, Vol. 3, Iss. 1, 55-66.

Defra (2010), Food 2030. Published by the Department for Environment, Food and Rural Affairs. January 2010.

Dong, G., DeFrancia, K., Chen, M., Filiatraut, B and Zhang, C.H. (2015), Assessing Sustainability: Frameworks and Indices (White Paper \#3), Columbia University Academic Commons, http://dx.doi.org/10.7916/D8BG2N4C

EEA (European Environmental Agency) CSI (2005), “EEA Core Set of Indicators,” EEA Technical Report No. 1/2005.

EEA, (European Environmental Agency) (2001). Total Material requirement of European Union, technical report No. 56, Copenhagen.

Elkington, J. (1998). Cannibals with forks: The triple bottom line of 21 st century business. Gabriola Island, BC: New Society Publishers.

EPfI (Environmental Performance Indicators) (2010), “2010 Environmental Performance Indicators," Yale Center for Environmental Law \& Policy / Center for International Earth Science Information Network In collaboration with World Economic Forum / Joint Research Centre of the European Commission, http://epi.yale.edu/file_columns/0000/0008/epi-2010.pdf.

EPrI (1999), “Towards Environmental Pressure Indicators for the EU,” Environment and Energy Paper Theme 8, Luxembourg, European Commission, http://biogov.cpdr.ucl.ac.be/communication/papers/ tepi99rp_EN105.pdf.

ESI (Environmental Sustainability Indicators) (2005), 2005 Environmental Sustainability Index: Benchmarking National Environmental Stewardship, Yale Center for Environmental Law and Policy / Center for International Earth Science Information Network, http://www.yale.edu/esi/ESI2005.pdf

Esty, D.C., Levy, M.A., Srebotnjak, T., de Sherbinin, A., Kim, Ch.H., and Anderson, B., (2006). Pilot Environmental Performance Index. Yale Center for Environmental Law \& Policy, New Haven.

EU, (1999). Towards Environmental Pressure Indicators for the EU, Environment and Energy Paper Theme 8, Luxembourg. T

Estes, R. (1974). A Comprehensive Corporate Social Reporting Model. Federal Accountant, pp. 9-20.

European Commission, (2000). Business Climate Indicator. DG ECFIN, European Commission, Brussels. 
European Commission, (2001b). Internal Market Scoreboard. DG MARKT, European

The Environmental Vulnerability Index (EVI), (2005). SOPAC Technical Report (Suva, Fiji Islands). SRU (Rat von Sachversta n̈digen für Umweltfragen) (1994).

Girardin, P., Bockstaller, C. and Van Der Werf, H. (1999), Indicators: Tools to evaluate the environmental impacts of farming systems, Journal of Sustainable Agriculture, Vol. 13, Iss. 4, pp. 5-21

Green, K.W. Jr., Zelbst, P.J. Meacham, J., and Bhadauria, V.S. (2012), Green supply chain management practices: impact on performance, Supply Chain Management: An International Journal, Vol. 17, Iss. 3, pp. $290-305$

GRI (Global Reporting Initiative) (2006), “Sustainability reporting Guidelines," version 3.0, 200-2006 GRI, http://www.globalreporting.org.

Hak, T., Kovanda, J. and Weinzettel, J. (2012,) A method to assess the relevance of sustainability indicators: Application to the indicator set of the Czech Republic's Sustainable Development Strategy. Ecological Indicators, Vol. 17, pp. 46-57

Halberg, N., van der Werf, H.M.G., Basset-Mens, C., Dalgaard, R. and de Boer, I.J.M. (2005), Environmental assessment tools for the evaluation and improvement of European livestock production systems, Livestock Production Science, Vol. 96, pp. 33-50.

Hansen, J.W. (1996), Is agricultural sustainability a useful concept? Agricultural Systems, Vol. 50, Iss. 2, pp. 117-143.

Helms, M. (2004), Food sustainability, food security and the environment, British Food Journal , Vol.106, Iss. 5, pp. 380-387.

Hervani, A.A., Helms, M.M., and Sarkis, J., (2005), Performance measurement for green supply chain management, Benchmarking: An International Journal, Vol. 12, Iss. 4, pp. 330-353

Hsu, A., Johnson, L. A., \& Lloyd, A. (2013). Measuring progress: A practical guide from the developers of the environmental performance index (EPI). New Haven: Yale Center for Environmental Law \& Policy.

ISO (International Organization for Standardization) (1999), Environmental managementEnvironmental Performance Evaluation-Guidelines, ISO 14031:1999(E), Geneva, Switzerland.

IUCN/IDRC (The World Conservation Union/International Development Research Center), (1995). Assessing progress towards sustainability: A new approach. In: Thadeus and Trzuna (Eds.), A sustainable world: Defining and measuring sustainable development. Sacramento, pp. 536 152-172. 

No. 37.

Joung, C.B., Carrell, J., Sarkar, P., and Feng, S.C. (2013), Categorization of indicators for sustainable manufacturing, Ecological indicators, Vol. 24, pp. 148-157

Jung, E.J., Kim, J.S., and Rhee, S.K. (2001). The measurement of corporate environmental performance and its application to the analysis of efficiency in oil industry. Journal of Cleaner

Production, Vol. 9, pp. 551-563.

Kondyli, J. (2010), Measurement and evaluation of sustainable development. A composite indicator for the islands of the North Aegean region, Greece. Environmental Impact Assessment Review, Vol. 30, Iss. 6, pp. 347-356.

Krajnc, D., and Glavic, P. (2005), A model for integrated assessment of sustainable development. Resour. Conserv. Recycling Vol. 43, pp. 189-208.

Labuschagne, C., Brent, A.C., van Erck, R.P.G. (2005), Assessing the sustainability performances of industries, Journal of Cleaner Production, Vol. 13, pp. 373-385

Lundin, U. (2003). Indicators for Measuring the Sustainability of Urban Water Systems-a Life Cycle Approach, PhD Thesis, Department of Environmental Systems Analysis, Chalmers University of Technology, Gothenburg, Sweden.

Lynam, J. K. and Herdt, R.W. (1989), Sense and sustainability: sustainability as an objective in international agricultural research, Agricultural Economics, Vol. 3, Iss. 1, pp. 381-398

Manning, L. (2015) Determining value in the food supply chain, British Food Journal, Vol. 117 Iss. 11, pp. $2649-2663$

Manning, L., Baines, R.N., and Chadd, S.A. (2007), Benchmarking the poultry meat supply chain, Benchmarking: An International Journal, Vol. 15, Iss. 2-3, pp. 148-165

Marketwatch (2015), Chipotle's disastrous 2015: What investors need to know, Available from: http://www.marketwatch.com/story/chipotles-disastrous-2015-what-investors-need-to-know2015-12-29 [Accessed on 30/12/15]

Mayle, D.T., Hinton, C.M., Francis, G.A.J. and Holloway, J.A. (2002), What really goes on in the name of benchmarking?, in Neely, A. (Ed.), Business Performance Measurement: Theory and Practice, Cambridge University Press, Cambridge, pp. 211-24.

Meadows, D. (1998). Indicators and Information Systems for Sustainable Development. Hartland Four Corners: The Sustainability Institute.

Mitchell, G., May, A. and McDonald, A. (1995), PICABUE: a methodological framework for the development of indicators of sustainable development, International Journal of Sustainable Development and World Ecology, Vol. 2, pp. 104-123.

Moldan, B. Janoušková, S. and Hák, T. (2012), How to understand and measure environmental sustainability: Indicators and targets, Ecological Indicators, Vol. 17, pp. 4-13 
Morris, D. (1979), Measuring the Condition of the World's Poor: The Physical Quality of Life

Index (Overseas Development Council). Pergamon Press, New York.

Muthuri, J., Moon J., and Matten, D. (2006), Employee Volunteering and the Creation of Social Capital, Research Paper Series International Centre for Corporate Social Responsibility No. 342006 - ISSN 1479-5124.

Narodoslawsky, M., and Krotscheck, C. (2004), What can we learn from ecological valuation of processes with the sustainable process index (SPI) - the case study of energy production systems, Journal of Cleaner Production, Vol. 12, pp. 111-115.

National Institute of Science and Technology Policy, (1995), Science and Technology Indicators, NISTEP Report No. 37, Japan.

Nestlé (2015a), Maggi noodles in India, Available at: http://www.nestle.com/ask-nestle/magginoodles-india-msg-lead-ban-recall [Accessed on 30.12.15]

Nestlé (2015b), Nestlé takes action to tackle seafood supply chain abuses Available at: http://www.nestle.com/media/news/nestle-tackles-abuses-seafood-supply-chain [Accessed on $30.12 .15]$

Niemeijer, D. (2002). Developing indicators for environmental policy: data-driven and theorydriven approaches examined by example, Environmental Science and Policy, Vol. 5, Iss. 2, pp. 91-103.

Nordhaus, W.D., Tobin, J., 1973. Is growth obsolete? In: Moss, M. (Ed.), The Measurement of Economic and Social Performance: Studies in Income and Wealth, Vol. 38.

Northcott, D. and Llewellyn, S. (2005), Benchmarking in UK health: a gap between policy and practice?, Benchmarking: An International Journal, Vol. 12, Iss. 5, pp. 419-35.

OECD CEI (2003), “OECD Environmental Indicators: Development, Measurement and Use," OECD Environmental Performance and Information Division, http://www.oecd.org/env.

Peano, C., Tecco, N., Dansero, E., Girgenti, V., and Sottile, F. (2015), Evaluating the Sustainability in Complex Agri-Food Systems: The SAEMETH Framework, Sustainability, Vol. 7, pp. 6721-6741

Pohl, E. (2006), Towards Corporate Sustainable development - ITT Flygt Sustainability Index, Licentiate Thesis, Malarden University

Prescott-Allen, R. (1995). Barometer of Sustainability: a Method of Assessing Progress towards Sustainable Societies. PADATA, Victoria, Canada.

Pretty, J. (1994), Alternative systems of inquiry for a sustainable agriculture, IDS Bulletin Vol. 25, Iss. 2, pp. 37-49.

Puolamaa, M., Kaplas, M., and Reinikainen, T. (1996), Index of Environmental Friendliness. A methodological study, Eurostat.

Ram, R. (1982), Composite Indices of Physical Quality of Life, basic Needs fulfillment, and 
Rigby. D., Woodhouse, P., Young, T. and Burton, M. (2001), Constructing a farm level indicator

of sustainable agricultural practice, Ecological Economics, Vol. 39, Iss. 3, pp. 463-478

Ronan, G. and Cleary, G. (2000), Best practice benchmarking in Australian agriculture: issues and challenges, Agribusiness Perspectives - Paper 39.

Saaty, T.L. (1980). The Analytic Hierarchy Process. McGraw-Hill Book Co., N.Y.

SAM Indexes (2007). The Dow Jones Sustainability Index. www.sustainability-index.com visited 2007-07-15.

Schmidt, W. and Taylor, A. (2006), "Ford of Europe's Product Sustainability Index,"

Proceedings of 13th CIRP International Conference on Life Cycle Engineering, Leuven, Belgium, pp. 5 - 10.

Schmidt-Bleek, (1994). How to reach a sustainable economy, Wuppertal Papers No. 24, Wuppertal, pp. 10-13.

Searcy, C., and Elkhawas, D., (2012), Corporate sustainability ratings: an investigation into how corporations use the Dow Jones Sustainability Index, Journal of Cleaner Production, 35 pp. 7992

Shrivastava (1995), The role of corporations in achieving ecological sustainability, Academy of Management Review, 20 (4): 936-60.

Singh, R. K., Murty, H. R., Gupta, S. K., and Dikshit, A. K. (2009). An overview of sustainability assessment methodologies. Ecological Indicators, Vol. 9, Iss. 2, 189-212

SOPAC (South Pacific Applied Geoscience Commission), 2005. Building resilience in SIDS. The Environmental Vulnerability Index (EVI) 2005. SOPAC Technical Report (Suva, Fiji Islands).

Storrie, D., and Bjurek, H. (1999), Benchmarking the Basic Performance Indicators Using Efficiency Frontier Techniques, Report Presented to the European Commission, Employment and Social Affairs DG.

Tan, H.X., Yeo, Z., Ng, R., Tjandra, T.B., and Song, B., (2015), A sustainability indicator framework for Singapore small and medium-sized manufacturing enterprises, The $22^{\text {nd }}$ CIRP conference on Life Cycle Engineering, Procedia CIRP, 29: 132-137

Tangen S. (2005), Insights from practice. Analysing the requirements of performance measurement systems, Measuring Business Excellence, Vol. 9 , Iss. 4, pp. 46-54

Taylor, A. (2012), Indicators, domains, and scoring methods for a Canadian Community Sustainability Indicator Framework. A thesis presented to the University of Waterloo in fulfilment of the thesis requirement for the degree of Master of Environmental Studies in Environment and Resource Studies Waterloo, Ontario, Canada, 2012. Available at: https://uwspace.uwaterloo.ca/bitstream/handle/10012/6773/Taylor_Allan.pdf\%3Bjsessionid=D C6B39768C7AF5450DB445C08E2D266B?sequence=1 [Accessed on: 01/10/2015] 
Thompson, P. B. and Nardone, A. (1999), Sustainable livestock production: methodological and ethical challenges. Livestock Production Science, Vol. 61, Iss. 2-3, pp. 111-119.

Turi, A., Goncalves, G., and Mocan, M. (2014), Challenges and Competitiveness Indicators for the Sustainable Development of the Supply Chain in Food Industry, Procedia - Social and Behavioral Sciences, Vol. 124, pp. 133-141

United Nations, (1990), Human Development Report. http:// www.undp.org.

UNDP, (2001), Human Development Report, Oxford University Press, New York.

UNDP, (1996), UNDP Strategy for Implementing its Gender in Development Policy. UNDP, New York.

UN-CSD (the United Nations Committee on Sustainable Development) (2007), Indicators of Sustainable Development: Guidelines and Methodologies (3rd Eds.), the United Nations, New York, New York, http://www.un.org/esa/sustdev/natlinfo/indicators/guidelines.pdf.

Veleva, V., and Ellenbecker, M. (2001), Indicators of sustainable production: framework and methodology, Journal of Cleaner Production, Vol. 9, pp. 519-549

Wackernagel, M., and Rees, W. (1996). Our ecological footprint: Reducing human impact on the earth. Gabriola Island, BC: New Society Publishers.

Wilson, J., Tyedmers, P., \& Pelot, R. (2007). Contrasting and comparing sustainable development indicator metrics. Ecological Indicators, Vol. 7, Iss. 2, pp. 299-314.

World Business Council for Sustainable Development (WBCSD). (1999). Eco-efficiency indicators and reporting: Report on the status of the project's work in progress and guidelines for pilot application. Geneva, Switzerland: Authors.

World Commission on Environment and Development (WCED) (1987). Our Common Future. New York: Oxford University Press.

World Economic Forum (WEF), (2002), An initiative of the Global Leaders of Tomorrow Environment Task Force. Annual Meeting 2002. Pilot Environment Performance Index. Available at http://www.ciesin.columbia.edu/indicators/ ESI/EPI2002_11FEB02.pdf.

Yakovleva, N., Sarkis, J. and Sloan, T. W. (2010). Sustainability indicators for the food supply chain. In, U. Sonesson, J. Berlin and F. Ziegler (Eds.). Environmental assessment and management in the food industry: Life cycle assessment and related approaches. Cambridge: Woodhead Publishing, pp. 297-329.

Yakovleva, N. (2007). Measuring the sustainability of the food supply chain: A case study of the UK. Journal of Environmental Policy and Planning, Vol. 9, Iss. 1, pp. 75-100.

Yakovleva, N. and Flynn, A. (2004). Innovation and sustainability in the food system: A case of chicken production and consumption in the UK. Journal of Environmental Policy and Planning, Vol. 6, Iss. 3-4, pp. 227-250.

Van Cauwenbergh, N., Biala, K., Bielders, C., Brouckaert, V., Franchois, L., Garcia Cidad, V., 
709 Hermy, M., Mathijs, E., Muys, B., Reijnders, J., Sauvenier, X., Valckx, J., Vanclooster, M., Van 710 der Veken, B., Wauters, E., and Peeters, A., (2007), SAFE - A hierarchical framework for 711 assessing the sustainability of agricultural systems, Agriculture, Ecosystems and Environment, 712 Vol. 120, Iss 2-4, pp. 229-242

713 Zolotas, X. (1981). Economic Growth and Declining Social Welfare. New York University Press. 


\begin{tabular}{|l|l|}
\hline \multicolumn{1}{|c|}{ Hervani et al. (2005) } & \multicolumn{1}{c|}{ Brewer and Speh (2001) } \\
\hline Geographical and cultural differences; & Differing organisational goals and objectives; \\
$\begin{array}{l}\text { Differences in organisational } \\
\text { philosophy and policy; }\end{array}$ & Overcoming mistrust and share data and information \\
Lack of technological integration; & Measuring factors which are not under direct control and are \\
Non-standardised data or poor & managed by others; \\
communication of measures; or & Inflexible information systems; \\
Lack of understanding of the need for & Non-standardised performance measures; \\
inter-organisational measures. & Difficulty in linking measures to stakeholder requirements and \\
& customer values; \\
& Lack of understanding; or \\
\hline
\end{tabular}

Table 2: Types of Benchmarking

\begin{tabular}{|c|c|c|}
\hline Benchmarking type & Definition & Source \\
\hline $\begin{array}{l}\text { Competitive } \\
\text { benchmarking } \\
\text { (operational) }\end{array}$ & $\begin{array}{l}\text { Most common form of benchmarking. Process of comparing between } \\
\text { competitors of a particular product or business function and could include } \\
\text { product specification, distribution or sales service. This is very often in } \\
\text { the form of a "league table" style approach. Advantage: Potential mutual } \\
\text { benefit of sharing of information. Disadvantage: Confidentiality } \\
\text { constraints may limit the free-flow of information and the outcomes of } \\
\text { the exercise. }\end{array}$ & $\begin{array}{l}\text { Bendell et al. } \\
\text { (1993) }\end{array}$ \\
\hline $\begin{array}{l}\text { Functional } \\
\text { benchmarking } \\
\text { (operational) }\end{array}$ & $\begin{array}{l}\text { Comparison of similar functions within the same broad industry or sector, } \\
\text { i.e. non-competitive organisations that carry out the same functional } \\
\text { activities e.g. Warehousing, administration or procurement. Advantage: } \\
\text { Open comparison and mutual sharing of information so there are no } \\
\text { issues with confidentiality. Disadvantage: Practices may need adapting } \\
\text { to suit specific industries. }\end{array}$ & $\begin{array}{l}\text { Bendell et al. } \\
\text { (1993) }\end{array}$ \\
\hline $\begin{array}{l}\text { Generic } \\
\text { benchmarking }\end{array}$ & $\begin{array}{l}\text { Comparison of business processes or functions that are similar regardless } \\
\text { of the industry. Advantage: Can develop innovative ideas. } \\
\text { Disadvantage: Practices identified may be novel and thus challenging to } \\
\text { implement. }\end{array}$ & $\begin{array}{l}\text { Bendell et al. } \\
\text { (1993) }\end{array}$ \\
\hline Ideas benchmarking & $\begin{array}{l}\text { Ideas benchmarking is about sharing information that in turn will drive } \\
\text { continuous improvement in organisational processes. }\end{array}$ & \multirow{2}{*}{$\begin{array}{l}\text { (Mayle et al. } \\
2002 \text { cited by } \\
\text { Northcott and } \\
\text { Llewellyn, } \\
\text { 2005) }\end{array}$} \\
\hline $\begin{array}{l}\text { Indicator } \\
\text { benchmarking }\end{array}$ & $\begin{array}{l}\text { Indicator benchmarking requires organisations to compare performance } \\
\text { against a range of measurable indicators. }\end{array}$ & \\
\hline $\begin{array}{l}\text { Internal } \\
\text { benchmarking }\end{array}$ & $\begin{array}{l}\text { Process of comparing internal operations within the same organisation. } \\
\text { Advantage: Easy to gain data. Disadvantage: Limited by organisation's } \\
\text { structure and does not necessarily define industry best practice. }\end{array}$ & $\begin{array}{l}\text { Bendell et al. } \\
\text { (1993) }\end{array}$ \\
\hline Lag benchmarking & $\begin{array}{l}\text { Benchmarking using measures that are historic data and change cannot be } \\
\text { instigated until the next crop or livestock cycle. }\end{array}$ & \multirow{2}{*}{$\begin{array}{l}\text { Anderson and } \\
\text { MacAdam } \\
(2004)\end{array}$} \\
\hline $\begin{array}{l}\text { Lead benchmarking } \\
\text { (operational) }\end{array}$ & $\begin{array}{l}\text { Benchmarking using measures that will instigate change often within the } \\
\text { crop or livestock cycle. }\end{array}$ & \\
\hline
\end{tabular}




\begin{tabular}{|c|c|c|}
\hline Indicator & Desired outcome & Comment \\
\hline \multicolumn{3}{|c|}{ Financial and physical capital indicators } \\
\hline Gross value added (GVA) per person. & $\begin{array}{l}\text { An agriculture sector focused on consumers' needs } \\
\text { through the market. }\end{array}$ & Deteriorated since 1990 - 2007 ratio of UK GVA to EU14 stands at 1.32 . \\
\hline $\begin{array}{l}\text { Total liabilities as a percentage of total } \\
\text { assets. }\end{array}$ & $\begin{array}{l}\text { A resilient agricultural sector that is able to withstand } \\
\text { and/or recover quickly from sudden or acute shocks. }\end{array}$ & $\begin{array}{l}\text { Total liabilities have remained at a relatively low level. Been on a declining trend as increases in asset } \\
\text { value (with the rise in land prices) had more than offset rise in liabilities. }\end{array}$ \\
\hline $\begin{array}{l}\text { Total factor productivity (TFP) of the } \\
\text { food chain beyond the farm gate. }\end{array}$ & Efficient and productive business across the food chain. & $\begin{array}{l}\text { Since } 1998 \text { food chain productivity has fallen behind rest of economy. Between } 1998 \text { and } 2006 \text { annual } \\
\text { average growth rate in food chain was } 0.11 \% \text { compared to } 0.43 \% \text { in wider economy. }\end{array}$ \\
\hline \multicolumn{3}{|c|}{ Human capital indicators } \\
\hline Innovative working practices. & $\begin{array}{l}\text { Investment in training. } \\
\text { Development and uptake of knowledge and innovation. }\end{array}$ & Skills and training pre-farm gate, food and drink manufacturing and processing. \\
\hline \multicolumn{3}{|c|}{ Natural capital indicators } \\
\hline Water abstraction for agriculture. & $\begin{array}{l}\text { Water resources used efficiently. } \\
\text { Environmental risks and pressures from abstraction } \\
\text { reduced. }\end{array}$ & $\begin{array}{l}\text { Agricultural uses accounted for } 0.5 \% \text { of recorded water abstraction in England and Wales in } 2006 \text {. } \\
\text { Regionally varied between } 0.1 \% \text { in NW and Wales and } 2.1 \% \text { in Anglian region When all forms of } \\
\text { irrigation are eventually licensed, the total volume will increase. }\end{array}$ \\
\hline $\begin{array}{l}\text { River Water Quality: nitrate and } \\
\text { phosphate levels in rivers. }\end{array}$ & Negative effects of agriculture on river quality decreased. & $\begin{array}{l}\text { Agriculture accounts for around } 61 \% \text { of the nitrate in rivers and around } 26 \% \text { of phosphates. In } 2007 \text {, } \\
32 \% \text { of river lengths exceeded } 30 \mathrm{mg} \mathrm{NO}_{3} \text { per litre fall from } 34 \% \text { in } 2006 \text {. Since } 2000 \text {, nitrate levels } \\
\text { fallen from around } 39 \% \text { of river lengths exceeded } 30 \mathrm{mg} \mathrm{NO}_{3} \text { per litre to } 32 \% \text { in } 2007 \text {. }\end{array}$ \\
\hline Pesticides in water. & Negative effects of agriculture on river quality decreased. & $\begin{array}{l}\text { In } 2007,6 \% \text { of the indicator samples contained pesticide concentrations above } 0.1 \mu \mathrm{g} / \mathrm{l} \text {. Reduction } \\
\text { from } 2006 \text { and typical of levels seen over previous years. }\end{array}$ \\
\hline Soil Quality: soil organic matter. & A healthy soil system utilised sustainably. & Soil level has been shown in various studies to be deteriorating. \\
\hline Soil Erosion. & Under development. & \\
\hline Biodiversity - water environment. & Under consideration. & \\
\hline $\begin{array}{l}\text { Status of farmland biodiversity action } \\
\text { plan (BAP) priority species and habitats } \\
\text { in England. }\end{array}$ & $\begin{array}{l}\text { Biodiversity of food producing systems maintained and } \\
\text { enhanced. }\end{array}$ & $\begin{array}{l}\text { Of the } 110 \text { species in the indicator, the number that were assessed as either 'stable' or 'increasing' } \\
\text { has risen from } 52 \text { to } 59 \text {, a } 13 \% \text { increase overall. In } 2008,37 \text { species still declining, including } 3 \text { species } \\
\text { recorded as lost from the UK as a whole since the BAP was published in } 1994 \text {. }\end{array}$ \\
\hline $\begin{array}{l}\text { The population of farmland birds in } \\
\text { England from } 1970 \text {. }\end{array}$ & $\begin{array}{l}\begin{array}{l}\text { Reverse the long term decline in farmland bird } \\
\text { populations. }\end{array} \\
\end{array}$ & $\begin{array}{l}\text { In } 2007 \text { index for all farmland species stood at } 49 \text {. Farmland specialist - continued slow decline since } \\
\text { 1970. Farmland generalist - little change since } 1970 .\end{array}$ \\
\hline $\begin{array}{l}\text { Changes in plant diversity in fields and } \\
\text { hedges on agricultural land in England. }\end{array}$ & $\begin{array}{l}\text { To conserve and restore productive land by reversing the } \\
\text { decline of plant diversity in fields and field margins. }\end{array}$ & $\begin{array}{l}\text { Arable and Horticultural land - some improvement since 1990. Other fields and field margins - little } \\
\text { improvement since } 1990 .\end{array}$ \\
\hline $\begin{array}{l}\text { Change in effective population size for } \\
\text { native breeds of sheep and cattle at } \\
\text { greatest risk of loss of genetic diversity. }\end{array}$ & $\begin{array}{l}\text { Genetic diversity of animals used for food production } \\
\text { sufficient to provide resilience. }\end{array}$ & Clear improvement since 2001. \\
\hline $\begin{array}{l}\text { Agricultures contribution to ammonia } \\
\text { emissions from agriculture. }\end{array}$ & Reduced ammonia emissions from agriculture. & $\begin{array}{l}\text { Since } 1990 \text { ammonia emissions from agriculture have fallen by } 20 \% \text { due, largely, to the contraction } \\
\text { in the pig herd and a reduction in direct soil emissions. There was little change in the level of ammonia } \\
\text { emissions between } 2005 \text { and } 2006 \text {. }\end{array}$ \\
\hline $\begin{array}{l}\text { Number and percentage of cattle tested } \\
\text { for TB that are slaughtered. }\end{array}$ & Incidence of bovine tuberculosis (TB) reduced. & $\begin{array}{l}\text { The number of cattle slaughtered in } 2008 \text { rose by nearly } 12,000 \text { to a figure of approximately } 39,000 \text {. } \\
\text { This is equivalent to a } 42 \% \text { increase on } 2007 \text { figures. }\end{array}$ \\
\hline \multicolumn{3}{|c|}{ Social capital indicators } \\
\hline $\begin{array}{l}\text { Trends in cases of illness due to food- } \\
\text { borne pathogens. }\end{array}$ & $\begin{array}{l}\text { Incidence of food borne disease in decline. } \\
\text { Incidence of food contamination in decline. }\end{array}$ & $\begin{array}{l}\text { Estimated cases of Listeria have more than doubled between } 2001 \text { and } 2007 \text {. Campylobacter most } \\
\text { prevalent food-borne illness. Cases of Salmonella in } 2007,23 \% \text { fewer than in } 2000 \text {. Since } 2000 \text {, } \\
\text { Salmonella contamination of UK-produced retail chicken reduced by } 50 \% \text {. }\end{array}$ \\
\hline
\end{tabular}


\begin{tabular}{|l|l|} 
Amount of British food covered by & An increasing amount of food can be traced to its source.
\end{tabular}

The poultry and dairy sectors have highest proportion of assured production at $95 \%$. Pig sector at

British assurance schemes $92 \%$ in 2007.

The demand for meat and meat products

Animal welfare standards.

Little or no change since 2005.

should not be at the expense of animal 
Table 4: Sustainability indicators and desired outcomes post farm gate and fishing (adapted from Defra, 2010)

\begin{tabular}{|c|c|c|}
\hline Indicator & Desired outcome & Comment \\
\hline \multicolumn{3}{|c|}{ Financial and physical capital indicators (None identified explicitly) } \\
\hline \multicolumn{3}{|c|}{ Human capital indicators } \\
\hline Innovative working practices. & $\begin{array}{l}\text { Investment in training. } \\
\text { Development and uptake of knowledge and innovation. }\end{array}$ & Skills and training pre-farm gate, food and drink manufacturing and processing. \\
\hline \multicolumn{3}{|c|}{ Natural capital indicators } \\
\hline Primary energy use in the UK food chain. & $\begin{array}{l}\text { A trend of continuing reduction in the energy use in the UK food chain } \\
\text { measured in terms of million tonnes oil equivalent. } \\
\text { A trend within declining total use, toward an increased proportion of } \\
\text { use of renewable energy. } \\
\text { Reduce greenhouse gas (GHG) emissions associated with food from } \\
\text { UK households. }\end{array}$ & $\begin{array}{l}\text { Primary energy use in the UK food chain: no assessment, indicator under } \\
\text { development. }\end{array}$ \\
\hline $\begin{array}{l}\text { Energy use in domestic food sectors: food } \\
\text { transport; food, drink and tobacco, } \\
\text { manufacturing; agriculture. }\end{array}$ & $\begin{array}{l}\text { A trend of continuing reduction in the energy use in the domestic food } \\
\text { chain measured in terms of tonnes oil equivalent. } \\
\text { A trend within declining total use, toward an increased proportion of } \\
\text { use of renewable energy. }\end{array}$ & Indicator provisional and under development. \\
\hline Water usage post farm gate. & Increased efficiency of direct water use in food processing. & Under development some data available. \\
\hline Waste reduction across the food chain. & Food and drink manufacturing waste. & $\begin{array}{l}\text { Insufficient data at present but indicators could be: } \\
\text { Waste generated per household per week. } \\
\text { Consumer attitudes to household waste. }\end{array}$ \\
\hline $\begin{array}{l}\text { UK urban food transport (proxy for urban } \\
\text { road congestion). } \\
\text { HGV transport of food for UK consumption } \\
\text { (proxy for infrastructure costs). }\end{array}$ & Reduced external impacts of food transport. & $\begin{array}{l}\text { Overall indicator for urban food transport is up by } 7 \% \text { in } 2006 \text {, and is now } 31 \% \text { higher } \\
\text { than in } 1992 . \text { Increase in urban food transport since } 2004 \text { due to more frequent and } \\
\text { longer shopping trips by car. HGV food kilometres declined by } 3 \% \text { in } 2006 \text {. Overseas } \\
\text { HGV food kilometres cover } 40 \% \text { of all HGV kilometres. }\end{array}$ \\
\hline $\begin{array}{l}\text { Percentage of UK fish stocks harvested } \\
\text { sustainably and at full reproductive capacity, } \\
1990 \text { to } 2007 \text {. }\end{array}$ & Wild fish stocks are managed and harvested in a sustainable way. & $\begin{array}{l}\text { During 1990s percentage of UK fish stocks considered to be harvested sustainably } \\
\text { and at full reproductive capacity was around } 10 \% \text {; it was } 5 \% \text { in } 2000 \text {, but has } \\
\text { increased to } 25 \% \text { in } 2007 \text {. Despite these increases, between } 70 \text { to } 75 \% \text { of UK fish } \\
\text { stocks have either reduced reproductive capacity or have been fished unsustainably } \\
\text { each year since } 2001 \text {. }\end{array}$ \\
\hline $\begin{array}{l}\text { Proportion of large fish by weight in the } \\
\text { northern North Sea }\end{array}$ & Wild fish stocks are managed and harvested in a sustainable way. & Little or no change since 1990. \\
\hline $\begin{array}{l}\text { Increasing food production sustainably: fish } \\
\text { imports. }\end{array}$ & Under development. & \\
\hline $\begin{array}{l}\text { Increasing food production sustainably: } \\
\text { sustainable fish consumption. }\end{array}$ & Under development. & \\
\hline $\begin{array}{l}\text { Increasing food production sustainably: } \\
\text { global fish stock. }\end{array}$ & Under development & \\
\hline \multicolumn{3}{|c|}{ Social capital indicators } \\
\hline $\begin{array}{l}\text { Level of cattle trade restrictions against the } \\
\text { UK on animal health grounds. }\end{array}$ & $\begin{array}{l}\text { UK animal health is of a high standard and the UK enjoys good export } \\
\text { relations to other countries. }\end{array}$ & $\begin{array}{l}\text { In } 1995 \text { UK beef and live cattle exports } £ 720 \text { million in } 2006 \text { after BSE restrictions } \\
\text { and then lifting of ban } £ 104 \text { million. }\end{array}$ \\
\hline $\begin{array}{l}\text { Consumers have access to an affordable, } \\
\text { health and varied diet. }\end{array}$ & Accessibility and affordability: Relative price of fruit and vegetables. & $\begin{array}{l}\text { Clear improvement since } 1990 \text { ( other indicators include low income households' } \\
\text { share of spending on food, food prices in real terms, household access to food stores, } \\
\text { purchasing behaviour in at risk groups (under development). }\end{array}$ \\
\hline
\end{tabular}


Consumer understanding and demand for

Engaged and informed consumers.

Under development in 2010.

tainable food.

Eating a healthy sustainable diet will create a

healthier society.

Food safety is key to public confidence in the

food system.

Assurance schemes give consumers

Diet related ill health: obesity.

Deterioration since 1995. Consumer confidence in food safety measures

Clear improvement since March 2001.

727 


\begin{tabular}{|c|c|}
\hline Sustainability measures & Source \\
\hline $\begin{array}{ll} & \text { Natural capital. } \\
\text { - } & \text { Efficiency levels of built capital. } \\
\text { - Structure (education, health, demographics, etc.) of human capital. } \\
\text { - } & \text { Human relationships for social capital. } \\
\text { - Well-being. }\end{array}$ & Meadows (1998) \\
\hline $\begin{array}{l}\text { - Ecological Footprint (EF): Calculates demands put on nature by humans (sources and sinks). Maintained by the global footprint network. } \\
\text { - Surplus Biocapacity (SB): Shows the difference between a nation's ecological capacity and their ecological footprint. } \\
\text { - Environmental Sustainability Index (ESI): Measures environmental, socio-economic, and institutional indicators... to assess sustainability. } \\
\text { - Well-being Index (WI): Combines human well-being and ecosystem well-being as a composite to assess sustainability. } \\
\text { - UN Human Development Index (HDI): Measuring three basic dimensions of human development: a long and healthy life, knowledge, and a } \\
\text { decent standard of living (UNDP, 2004) used as a proxy of sustainability. } \\
\text { - GDP: economic growth. }\end{array}$ & Wilson et al. (2007) \\
\hline $\begin{array}{ll} & \text { State of the Nation's Ecosystem Report (the Heinz Report). } \\
\text { - } & \text { Ecological Indicators for the Nation Report (NRC Report). } \\
\text { - } & \text { Environmental Sustainability Index (ESI). }\end{array}$ & Niemeijer (2002) \\
\hline
\end{tabular}


Triple Bottom Line (TBL) Sustainability Frameworks

TBL framework that represents social, environmental and economic pillars of sustainability

Global Reporting Initiative (GRI) - TBL framework - 84 indicators across 3 pillars.

Pressure State Response (PSR) framework - evolved to the Driver-Pressure-State-Response (DPSIR) model that considers how people influence their surrounding environment and then how it reacts i.e. the impact of actions on the environment.

UN Commission for Sustainable Development's Theme indicator Framework - TBL framework plus institutional elements - 38 sub-themes.

Sustainability Assessment of farming and the Environment (SAFE) framework

Institute of Chemical Engineers Sustainability Metrics - TBL framework

Wuppertal Sustainability Indicators (WSI) - TBL framework plus institutional elements.

Sustainable Agri-Food Evaluation Methodology" (SAEMETH) - 52 indicators
Dong et al. (2015); Elkington (1998)

Dong et al. (2015) Das and Das (2014); Labuschagne et al.

(2005)

Singh et al. (2009)

Dong et al. (2015); Labuschagne et al. (2005)

Van Cauwenbergh et al. (2007)

Labuschagne et al. (2005)

Labuschagne et al. (2005)

Peano et al. (2015)

Qualitative Evaluation of composite TBL indicators

Barometer of Sustainability - combined evaluation of environmental and social aspects of sustainability.

Dong et al. (2015); Singh et al. (2009); Prescott-Allen (1995); IUCN-IDRC (1995)

Eco-Efficiency Framework assists businesses to assess their sustainable development using combined economic and environmental indicators

Ecological Footprint - area of land needed to produce enough food, water, energy, as well as to dispose of waste for a person, a product or a city - 6 indicators

Dong et al. (2015); WBSCD (1999)

Dong et al. (2015); Moldan et al. (2012); Singh et al. (2009);

Böhringer and Jochem (2007); Wackernagel and Rees (1996)

Single-issue Sustainability Frameworks

Lowell Centre for Sustainable Production Framework system of environmental sustainability indicators specifically designed for the production process. Five levels:

facility compliance/conformance indicators, facility material use and performance indicators, facility effect indicators, supply chain and product life-cycle indicators,

and sustainable system indicators

Independent Frameworks

Competing Values Framework, and the Approach, Deployment, Results, and Improvement (ADRI) assessment matrix. 


\section{Examples of Sustainability Indices}

Business Climate Indicator (BCI) -5 indicators

City Development Index (CDI) -11 indicators

Compass Index of Sustainability (CIS) -4 categories of indicators

Composite Sustainable Development Index (CSDI) -38 indicators

Composite Sustainability Performance Index (CSPI) -59 indicators

Dashboard of Sustainability (DoS)

Dow Jones Sustainability Group Indices (DJSGI) - based on five elements: technology, governance, shareholders, industry, society

Eco-efficiency indices (EEI)

Economic Aspects of Welfare (EAW

Ecosystem Wellbeing Index (EWI)

Environmental Adjusted Domestic Product (EDP)

Environmental Performance Index (EPIa) - 6 headline indicators with sub-indicators

\section{Environmental Pressure Indicators (EPIb)}

Environmental Quality Index (EQI) - based on multi-attribute utility theory

Environmental Sustainability Index (ESI) -68 indicators

Environmental Vulnerability Index (EVI) -50 indicators

European Labour Market Performance (ELMP) - 3 indicators: unemployment rate, long-term unemployment rate and youth unemployment rate

FTSE Good Index

Ford Product Sustainability Index (Ford PSI) -8 indicators

Gender Empowerment Measure (GEM)

General Indicator of Science and Technology (GIST) -13 indicators

Genuine Progress Indicator (GPI)

Genuine Savings Index (GSI) -3 capitals -5 indicators

G Score -5 categories

Human Development Index (HDI) - three elements include quality of industrial relations and labor conditions, education (input and maintenance of human capital) and income level and distribution.

Index of Environmental Friendliness -(IEF) - 11 indicators

Index of Sustainable Economic Welfare (ISEW) - main focus to measure the portion of economic activity that delivers welfare to people as a replacement for gross domestic product (GDP) - 20 sub-indicators

Index of Sustainable Society (ISS) -5 categories; 22 indicators

Internal Market Index (IMI) -19 indicators

ITT Flygt Sustainability Index -40 indicators

Life Cycle Index (LCI)- 4 categories; 21 indicator

Living Planet Index (LPI) - 2000 populations of more than 11,000 species -1100 variables

Material Input per Service Unit (MIPS)

Measure of Economic Welfare (MEW)

Physical Quality of Life Index (PQLI)

Summary Innovation Index (SII) - 17 indicators

Sustainable Asset Management (SAM) - 225 indicators

Sustainable Cities Index -13 indicators

Sustainability Performance Index (SPIa) - 5 indicators

Sustainable Process Index (SPIb)

Technology Achievement Index (TAI) -8 indicators

Total Material Requirement (TMR)

Wellbeing Index (WBI) -87 indicators

737

\section{Source}

Singh et al. (2009); European Commission (2000) Singh et al. (2009); Böhringer and Jochem (2007) Singh et al. (2009); Atkinson et al. (1997)

Singh et al. (2009); Krajnc and Glavic (2005);

Singh et al. (2009); Singh et al. (2007)

\section{Singh et al. (2009)}

Singh et al. (2009); Dow Jones/SAM (2007)

Singh et al. (2009); WBCSD (1999)

Singh et al. (2009): Brekke (1997): Zolatas (1981)

Dong et al. (2015)

Böhringer and Jochem (2007)

Dong et al. (2015); Hsu et al. (2013); Singh et al. (2009); Böhringer and Jochem (2007); Esty et al. (2006); WEF (2002)

Singh et al. (2009); EU (1999)

Singh et al. (2009); Saaty (1980)

Dong et al. (2015); Singh et al. (2009); Böhringer and Jochem (2007) WEF (2002)

Dahl (2012); Singh et al. (2009); Böhringer and Jochem (2007); SOPAC (2005)

Singh et al. (2009); Storrie and Bjurek (1999)

Singh et al. (2009)

Singh et al. (2009)

Singh et al. (2009); UNDP (1996)

Singh et al. (2009); Böhringer and Jochem (2007); Cobb et al. (1995)

Singh et al. (2009); Böhringer and Jochem (2007)

Singh et al. (2009); Jung et al. (2001)

Dong et al. (2015); Moldan et al. (2012); Singh et al. (2009); Böhringer and Jochem (2007); Labuschagne et al. (2005); UN (1990)

Singh et al. (2009); Puolamaa et al. (1996)

Dong et al. (2015); Singh et al. (2009); Böhringer and Jochem (2007); Daly and Cobb (1989)

Singh et al. (2009)

Singh et al. (2009); EC (2001b)

Singh et al. (2009); Pohl (2006)

Singh et al. (2006)

Dong et al. (2015); Böhringer and Jochem (2007); Singh et al. (2009);

Singh et al. (2009); Schmidt-Bleek (1994)

Singh et al. (2009); Nordhaus and Tobin (1973)

Dong et al. (2015); Singh et al. (2009); Ram (1982): Morris (1979)

Singh et al. (2009); Economic Commission (2001a)

Singh et al. (2009)

Sing et al. (2009)

Singh et al. (2009); Narodoslawsky and Krotscheck (2004); Lundin (2003)

Dong et al. (2015); Singh et al. (2009);

Sing et al. (2009); UNDP (2001)

Singh et al. (2009); EEA (2001)

Singh et al. (2009); Böhringer and Jochem (2007) 
Table 8. Sustainability indicator sets and the levels at which they operate (Adapted from Joung et al. 2013)

\begin{tabular}{|l|c|c|c|l|}
\hline & $\begin{array}{c}\text { Company/ } \\
\text { Organisational } \\
\text { level }\end{array}$ & $\begin{array}{c}\text { National/ } \\
\text { region } \\
\text { level }\end{array}$ & \multicolumn{1}{|c|}{$\begin{array}{c}\text { Global } \\
\text { level }\end{array}$} & \multicolumn{1}{|c|}{ Source } \\
\hline Japan National Institute of Science and Technology (NISTEP) & $\mathrm{X}$ & & & JSTA (1995) \\
\hline Dow Jones Sustainability Indexes (DJSI) & $\mathrm{X}$ & & & SAM Index (2007) \\
\hline Global Report Initiative (GRI) & $\mathrm{X}$ & & & GRI (2006); Staniskis (2009) \\
\hline Environment Performance Evaluation (EPE) standard (ISO 13031) & $\mathrm{X}$ & & & ISO (1999) \\
\hline Ford Product Sustainability Index (Ford PSI) & & $\mathrm{X}$ & & Schmidt and Taylor (2006) \\
\hline 2005 Environmental Sustainability Indicators (ESI) & & $\mathrm{X}$ & & ESI (2005) \\
\hline Environmental Performance Index (EPIa) & & $\mathrm{X}$ & $\mathrm{X}$ & EPfI (2010) \\
\hline Environmental Pressure Indicators (EPIb) & $\mathrm{X}$ & & UN-CSD (2007) \\
\hline United Nations- Indicators of Sustainable Development (UN-CSD) & $\mathrm{X}$ & & OECD CEI (2003) \\
\hline $\begin{array}{l}\text { Organisation for Economic Cooperation and Development (OCED) Core } \\
\text { Environmental Indicators (CEI) }\end{array}$ & & $\mathrm{X}$ & & EEA-CSI (2005) \\
\hline European Environmental Agency Core Set of Indicators (EEA-CSI) & & & \\
\hline
\end{tabular}


741 Table 9: TBL supply chain sustainability indicators that operate at the product and organisational level (Adapted from Tan et al. (2015); 742 Turi et al. (2014); Yakovleva et al. (2010); Veleva and Ellenbecker (2001))

\begin{tabular}{|c|c|c|c|c|c|}
\hline $\begin{array}{c}\text { Sustainability } \\
\text { development } \\
\text { objective }\end{array}$ & $\begin{array}{l}\text { Measurement } \\
\text { criteria }\end{array}$ & $\begin{array}{l}\text { Sustainability indicator } \\
\text { Yakovleva et al. (2010) }\end{array}$ & Veleva and Ellenbecker (2001) & $\begin{array}{l}\text { Sustainability indicator } \\
\text { (Turi et al. (2014) }\end{array}$ & Tan et al. (2015) \\
\hline \multicolumn{6}{|c|}{ Economic dimension } \\
\hline $\begin{array}{l}\text { Promotion of } \\
\text { economic growth }\end{array}$ & Productivity & $\begin{array}{l}\text { Indicator 1: Gross value } \\
\text { added per workforce (\$) }\end{array}$ & & $\begin{array}{l}\text { Number of improvement } \\
\text { suggestions submitted by } \\
\text { employees }\end{array}$ & $\begin{array}{l}\text { Material costs }(\$) \\
\text { Energy costs }(\$) \\
\text { Costs saved }(\$) \\
\text { Operational and capital costs }(\%)\end{array}$ \\
\hline $\begin{array}{l}\text { Financial } \\
\text { viability }\end{array}$ & Profitability & Indicator 2: Profitability (\$) & Costs associated with non-compliance (\$) & & $\begin{array}{l}\text { Net profit margin }(\$) \\
\text { Environmental fines and penalties }(\$) \\
\text { Innovation and R/D investments }(\$)\end{array}$ \\
\hline Worthwhileness & Return on capital & $\begin{array}{l}\text { Indicator 3: Return on capital } \\
\text { employed (ROCE \%) }\end{array}$ & & & Return on investment (\$) \\
\hline Human capital & $\begin{array}{l}\text { Employee } \\
\text { engagement }\end{array}$ & & $\begin{array}{l}\text { Rate of employees' suggested improvements in } \\
\text { quality, social and EHS performance. }\end{array}$ & & Employee environmental suggestions (Number) \\
\hline \multicolumn{6}{|c|}{ Social dimension } \\
\hline \multirow{3}{*}{$\begin{array}{l}\text { Creation of } \\
\text { productive } \\
\text { employment }\end{array}$} & $\begin{array}{l}\text { Free association } \\
\text { of labour }\end{array}$ & $\begin{array}{l}\text { Indicator 4: Freedom of } \\
\text { employment }(\%)\end{array}$ & & & \\
\hline & $\begin{array}{l}\text { Community/ } \\
\text { stakeholder } \\
\text { engagement }\end{array}$ & & Number of community-company partnerships & $\begin{array}{l}\text { Management levels with specific } \\
\text { environmental responsibilities }\end{array}$ & $\begin{array}{l}\text { Sustainability reports (number) } \\
\text { Environmentally certified service providers (\%) } \\
\text { Sustainability initiatives (number) } \\
\text { Achieved objectives }(\%)\end{array}$ \\
\hline & $\begin{array}{l}\text { Quality of } \\
\text { employment }\end{array}$ & $\begin{array}{l}\text { Indicator 5: Average wages } \\
\text { per person }(\$)\end{array}$ & $\begin{array}{l}\text { Number of Employees per unit of product or per } \\
\$ \text { sold. } \\
\text { Lost workday injury and illness case rate. } \\
\text { Turnover rate or average length of service of } \\
\text { employees (years). } \\
\text { Average hours of employee training per year. }\end{array}$ & $\begin{array}{l}\text { Number of Employees trained/to be } \\
\text { trained }\end{array}$ & $\begin{array}{l}\text { Labour costs (\$) } \\
\text { Lost workdays (days) } \\
\text { Employee attrition (turnover) rate } \\
\text { Personal protective and safety equipment provision (\%) } \\
\text { Line stops due to safety concerns (\%) } \\
\text { Labour productivity (\$) } \\
\text { Average hours of sustainability training (hours) } \\
\text { Employees trained in sustainability }(\%)\end{array}$ \\
\hline $\begin{array}{l}\text { Product/service } \\
\text { safety and } \\
\text { integrity }\end{array}$ & $\begin{array}{l}\text { Risk associated } \\
\text { with use or } \\
\text { consumption of } \\
\text { product }\end{array}$ & $\begin{array}{l}\text { Indicator 6: Product/service } \\
\text { failure rate }(\%)\end{array}$ & $\begin{array}{l}\text { Rate of defective products (\%) } \\
\text { Rate of customer complaints and returns (Number } \\
\text { per product sold) } \\
\text { Percentage of products designed for disassembly, } \\
\text { reuse, recycling. } \\
\text { Percentage of biodegradable packaging }\end{array}$ & $\begin{array}{l}\text { Perfect order delivery (percentage) } \\
\text { Product life remaining (percentage) } \\
\text { Number of "green" products }\end{array}$ & $\begin{array}{l}\text { Rate of defective products (\%) } \\
\text { Customer complaints (number) }\end{array}$ \\
\hline \multicolumn{6}{|c|}{ Environmental dimension } \\
\hline \multirow[t]{2}{*}{$\begin{array}{l}\text { Reduction in } \\
\text { resource use }\end{array}$} & $\begin{array}{l}\text { Material } \\
\text { consumption }\end{array}$ & & $\begin{array}{l}\text { Material used (total }(\mathrm{kg}) \text { and } \mathrm{kg} \text { per unit of } \\
\text { product) }\end{array}$ & & $\begin{array}{l}\text { Packaging materials reused (kg/unit) } \\
\text { Materials saved from implemented initiatives }(\mathrm{kg} / \mathrm{kg})\end{array}$ \\
\hline & $\begin{array}{l}\text { Energy } \\
\text { consumption }\end{array}$ & $\begin{array}{l}\text { Indicator 7: Energy } \\
\text { consumption per unit of } \\
\text { output (Energy unit/tonne) }\end{array}$ & $\begin{array}{l}\text { Energy used (total (kWh) and } \mathrm{kWh} \text { per unit of } \\
\text { product) } \\
\text { Energy from renewables (\%) } \\
\text { Tons of } \mathrm{CO}_{2} \text { equivalent }\end{array}$ & $\begin{array}{l}\text { Energy use per unit of production } \\
\mathrm{CO}_{2} \text { emissions per unit of } \\
\text { production }\end{array}$ & $\begin{array}{l}\text { Total energy used }(\mathrm{kWh}) \text { and }(\mathrm{kWh} / \mathrm{unit}) \\
\text { Energy saved from implementation initiatives }(\mathrm{kWh} / \mathrm{kWh}) \\
\text { Energy generated from byproducts }(\mathrm{kWh}) \\
\text { Energy efficiency }(\mathrm{kWh} / \text { product sold } \$)\end{array}$ \\
\hline
\end{tabular}




\begin{tabular}{|c|c|c|c|c|c|}
\hline & & & & $\begin{array}{l}\text { Transport costs per unit of } \\
\text { production }\end{array}$ & $\begin{array}{l}\text { Greenhouse gas emissions }\left(\mathrm{kgCO}_{2} \mathrm{e}\right) \\
\text { Vehicle fuel saved (1 saved/l used) }\end{array}$ \\
\hline & $\begin{array}{l}\text { Water } \\
\text { consumption }\end{array}$ & $\begin{array}{l}\text { Indicator } 8: \text { Water } \\
\text { consumption per unit of } \\
\text { output }\left(\mathrm{m}^{3} / \text { tonne }\right)\end{array}$ & Fresh water consumption (l) & & $\begin{array}{l}\text { Water used }\left(\mathrm{m}^{3 /} / \mathrm{unit}\right) \\
\text { Water reused }\left(\mathrm{m}^{3}\right)\end{array}$ \\
\hline $\begin{array}{l}\text { Protection of } \\
\text { natural } \\
\text { environment }\end{array}$ & Waste production & $\begin{array}{l}\text { Indicator 9: Waste } \\
\text { production per unit of output } \\
(\%)\end{array}$ & $\begin{array}{l}\text { Waste generated before recycling (emissions, } \\
\text { solid and liquid waste) }\end{array}$ & $\begin{array}{l}\text { Reverse logistics (reduce, reuse, } \\
\text { recycle) }\end{array}$ & $\begin{array}{l}\text { Volume of waste water discharged }\left(\mathrm{m}^{3}\right) \\
\text { Solid waste produced }(\mathrm{kg}) \\
\text { Reused/recycled materials used in products (kg/unit) } \\
\text { Packaging materials discarded (kg/unit) }\end{array}$ \\
\hline
\end{tabular}


Table 10. Sustainability Indicator Scoring (SIS) Matrix (modified from Yakovleva et al. 2010)

\begin{tabular}{|c|c|c|c|c|c|c|c|c|c|c|c|c|c|c|c|c|}
\hline \multirow{2}{*}{$\begin{array}{l}\text { Sustainability indicator } \\
\text { Qualitative assessment }\end{array}$} & \multicolumn{7}{|c|}{ Current status (baseline) } & \multicolumn{7}{|c|}{ Future status (goal) } & \multirow{2}{*}{$\begin{array}{c}\text { Combined score } \\
\text { (current score } x \text { future } \\
\text { score) }\end{array}$} & \multirow[t]{2}{*}{ Rationale for decision } \\
\hline & $\begin{array}{l}\text { No } \\
\text { data }\end{array}$ & $\begin{array}{l}\text { Very } \\
\text { poor }\end{array}$ & Poor & Fair & Average & Good & Excellent & $\begin{array}{l}\text { No } \\
\text { data }\end{array}$ & $\begin{array}{l}\text { Very } \\
\text { poor }\end{array}$ & Poor & Fair & Average & Good & Excellent & & \\
\hline Sustainability score & 0 & 1 & 2 & 3 & 4 & 5 & 6 & 0 & 1 & 2 & 3 & 4 & 5 & 6 & & \\
\hline Economic & & & & & & & & & & & & & & & & \\
\hline $\begin{array}{l}\text { Indicator 1: Gross value } \\
\text { added per workforce (\$) }\end{array}$ & & & & & & & & & & & & & & & & \\
\hline Indicator 2: Profitability (\$) & & & & & & & & & & & & & & & & \\
\hline $\begin{array}{l}\text { Indicator 3: Return on capita } \\
\text { employed (ROCE \%) }\end{array}$ & & & & & & & & & & & & & & & & \\
\hline $\begin{array}{l}\text { Indicator 4: Employee } \\
\text { engagement (number of } \\
\text { initiatives) }\end{array}$ & & & & & & & & & & & & & & & & \\
\hline Social & & & & & & & & & & & & & & & & \\
\hline $\begin{array}{l}\text { Indicator 5: Community/ } \\
\text { stakeholder engagement } \\
\text { (number of initiatives) }\end{array}$ & & & & & & & & & & & & & & & & \\
\hline $\begin{array}{l}\text { Indicator 6: Freedom of } \\
\text { employment }(\%)\end{array}$ & & & & & & & & & & & & & & & & \\
\hline $\begin{array}{l}\text { Indicator 7: Average wages } \\
\text { per person (\$) }\end{array}$ & & & & & & & & & & & & & & & & \\
\hline $\begin{array}{l}\text { Indicator 8: Product/service } \\
\text { failure rate }(\%)\end{array}$ & & & & & & & & & & & & & & & & \\
\hline Environmental & & & & & & & & & & & & & & & & \\
\hline $\begin{array}{l}\text { Indicator 9; Material } \\
\text { consumption per unit of } \\
\text { output (tonne/tonne) }\end{array}$ & & & & & & & & & & & & & & & & \\
\hline $\begin{array}{l}\text { Indicator 10: Energy } \\
\text { consumption per unit of } \\
\text { output (Energy unit/tonne) }\end{array}$ & & & & & & & & & & & & & & & & \\
\hline $\begin{array}{l}\text { Indicator 11: Water } \\
\text { consumption per unit of } \\
\text { output }\left(\mathrm{m}^{3} / \text { tonne }\right)\end{array}$ & & & & & & & & & & & & & & & & \\
\hline $\begin{array}{l}\text { Indicator 12: Waste } \\
\text { production per unit of output } \\
(\%)\end{array}$ & & & & & & & & & & & & & & & & \\
\hline Total & & & & & & & & & & & & & & & & \\
\hline
\end{tabular}

\section{Ranking criteria}

0 : Indicates no available data;

1-72 = Very low sustainability (VLS) i.e. the combined score shows a need for urgent improvements; actions need to be taken and reassessed after improvement measures have been implemented to determine efficacy;

73-144 = Low sustainability (LS) - the score shows a need for evaluation to determine areas for improvements and the prioritisation for action is high priority. Action needs to be taken and then they should be re-assessed after improvements have been implemented to determine efficacy;

145-216 = Fair sustainability (FS) the score shows improvements are required with medium priority Action needs to be taken and then they should be re-assessed after improvements have been implemented to determine efficacy;

217-288 = Average sustainability (AS) the score shows a need for evaluation to determine areas for improvements but this is of low priority. Action needs to be taken and then they should be re-assessed after improvements have been implemented to determine efficacy;

289-360 = Good sustainability (GS) - the score shows this area is under control but continuous improvement can still be made to achieve excellent status

361-432 = Excellent sustainability (ES) where an organisation can demonstrate sustainability goals are being achieved and documented plans and policies and an associated monitoring and verification system ensure there are formal systems in place to underpin maintaining this level of efficiency. 